\title{
GENETIC DIVERSITY AND ANTIMICROBIAL RESISTANCE OF ENTEROCOCCAL ISOLATES FROM SOUTHERN REGION OF BRAZIL
}

\author{
Pedro Alves d'AZEVEDO(1), Cícero Armídio Gomes DIAS(1) \& Lúcia Martins TEIXEIRA(2)
}

\begin{abstract}
SUMMARY
In the present study, a total of 455 enterococcal isolates, recovered from patients living in the city of Porto Alegre, State of Rio Grande do Sul, Brazil, during the period from July 1996 to June 1997, were identified to the species level by conventional biochemical and microbiological tests, and assayed for their susceptibilities to antimicrobial agents. The genetic diversity of antimicrobial resistant strains was evaluated by pulsed-field gel electrophoresis (PFGE) analysis of SmaI restricted chromosomal DNA. The most frequent species was Enterococcus faecalis $(92.8 \%)$. Other species identified were: E. faecium (2.9\%), E. gallinarum $(1.5 \%)$, E. avium (1.1\%), E. hirae (0.7\%), E. casseliflavus $(0.4 \%)$, E. durans $(0.4 \%)$ and E. raffinosus $(0.2 \%)$. The overall prevalence of isolates with high-level resistance (HLR) to aminoglycosides was $37.8 \%$. HLR to gentamicin was found in $24.8 \%$. No strains with acquired resistance to vancomycin were found. PFGE analysis showed the predominance of clonal group A, comprising strains isolated from different clinical specimens obtained from patients in three hospitals. These results suggest intra and interhospital dissemination of one predominant clonal group of E. faecalis isolates with HLR to gentamicin in the hospitals included in this study.
\end{abstract}

KEYWORDS: Enterococci; High level resistance aminoglycosides; Genetic diversity.

\section{INTRODUCTION}

Enterococci have become one of the most prominent nosocomial pathogens in the last few decades ${ }^{14,19}$. Resistance to several classes of antimicrobial agents is a remarkable characteristic of enterococcal isolates increasingly reported worldwide ${ }^{6,16}$. Bactericidal antimicrobial activity, necessary for the treatment of enterococcal infections, is usually obtained by the sinergistic combination of a cell-wall active agent, such as a $\beta$-lactam or a glycopeptide, with an aminoglycoside, such as gentamicin or streptomycin. However, the efficacy of this antimicrobial therapy has been threatened by the increasing occurrence of high level resistance to gentamicin (HLR-Ge) and streptomycin (HLR-St) among enterococci in several countries ${ }^{7,13,16}$ including in Brazil ${ }^{1,10,12,18,20}$.

Different molecular methods have been used to study the epidemiology and diversity of enterococci isolates expressing multidrug-resistence, including pulsed-field gel electrophoresis (PFGE) and polymerase chain reaction (PCR), but PFGE has been considered the method of choice for typing enterococcal isolates ${ }^{22,23}$.

The increasing prevalence of high level aminoglycoside resistance among enterococcal isolates recovered in hospitals in Brazil has been documented, and the results of molecular studies using PFGE suggested the presence and spread of two clonal groups ${ }^{1,10,18}$. The level of aminoglycoside resistance and the clonal characteristics of strains isolated in the Southern region of Brazil are still unknow. Considering the increased occurrence of antimicrobial resistant enterococcal isolates, the importance of these microorganisms as a cause of nosocomial infections, and the lack of information about enterococci isolates in the southern part of Brazil, we decided to evaluate the phenotypic and genotypic characteristics of a diverse collection of 455 enterococci isolates recovered in the city of Porto Alegre, located in the state of Rio Grande do Sul (RS), a southern city in Brazil. We (1) identify the isolates to the species level, (2) evaluate the isolates susceptibility to antimicrobials usually used for treatment of enterococcal infections, (3) investigate the genetic diversity of these isolates using PFGE, and (4) correlate the high level resistance (HLR) with clonal groups defined by PFGE.

\section{MATERIALS AND METHODS}

Bacterial isolates: A total of 455 enterococcal isolates recovered from patients receiving medical care in five different hospitals located in the city of Porto Alegre, RS state, Brazil, were collected during the period from July 1996 to June 1997. These isolates were recovered from different clinical specimens, Table 1. A total of five reference strains were used as controls: Enterococcus faecalis ATCC 29212 (susceptible to vancomycin, streptomycin and gentamicin), Enterococcus faecium SS 1274, E. faecalis 
CL-445 (high-level resistant to gentamicin [HLR-Ge]), E. faecalis SS1332 (high-level resistant to gentamicin and streptomycin [HLR-GeSt] and vancomycin resistant) and E. faecium (high-level resistant to streptomycin and ampicillin [HLR-St/Ap]). All reference strains were obtained from the Streptococcus Laboratory of the Centers for Disease Control and Prevention (CDC), Atlanta, Georgia, USA.

Identification isolates: All 455 strains were tested for their phenotypic characteristics by conventional biochemical tests as recommended by FACKLAM \& TEIXEIRA $^{3}$ and FACKLAM et al. ${ }^{4}$. For some isolates with atypical phenotypic identification, analysis of whole-cell protein profiles by sodium dodecyl-sulfate-polyacrylamide gel electrophoresis (SDS-PAGE) was performed to confirm identification according to TEIXEIRA et $a l .{ }^{21}$.

Antimicrobial susceptibility test: Susceptibility to vancomycin, and HLR to aminoglycosides were tested by the agar screening method as recommended by the NCCLS (National Committee for Clinical Laboratories Standards) ${ }^{17}$. HLR to ampicillin was tested by using Mueller- Hinton agar plates containing $16 \mu \mathrm{g} / \mathrm{mL}$ of this $\operatorname{drug}^{20}$. Resistant strains were confirmed by the E test (AB Biodisk, Solna, Sweden). Isolates were tested for $\beta$-lactamase production by the chromogenic cephalosporin (nitrocefin) disk method (Becton Dickinson Diagnostic Systems, Sparks, Maryland, USA).

DNA extraction and restriction fragment analysis by PFGE: Chromosomal DNA was obtained as described by TEIXEIRA et al. ${ }^{21}$.
Purified DNA was digested with the restriction enzyme SmaI (Boehringer Mannheim Corporation, Indianapolis, Ind.) and separated by PFGE in $1.2 \%$ agarose gels, using a CHEF-DRIII system (Bio-Rad Laboratories, Richmond, Calif.). The pulse time was increased from 5 to 35 s, over 22 hours at $6 \mathrm{~V} / \mathrm{cm}$ with the temperature of $11^{\circ} \mathrm{C}$ and a $120^{\circ}$ angle. Analysis of chromosomal DNA fragmentation profiles was performed by visual inspection of the photographic register of ethidium bromide stained gels according to TENOVER et al..$^{22}$. Computer-assisted comparison of the PFGE profiles was performed by using the Molecular Analyst Fingerprinting Plus software package, version 1.12, of the Image Analysis System (BioRad), and percentages of similarities of the profiles were estimated with the Dice coefficient and clustered by the unweighted pair group method with arithmetic averages (UPGMA).

\section{RESULTS AND DISCUSSION}

Table 1 shows the distribution of enterococcal species according to the source of isolation. The most frequent isolation source was urine (320 isolates; 70.3\%), followed by different types of secretions (94 isolates; 20.7\%), blood (12 isolates; 2.6\%), catheters (11 isolates; $2.4 \%$ ) and other miscellaneous sources (18 isolates; 4.0\%). The most frequent species was E. faecalis $(92.8 \%)$. Other species identified were: E. faecium (2.9\%), E. gallinarum (1.5\%), E. avium (1.1\%), E. hirae $(0.7 \%)$, E. casseliflavus $(0.4 \%)$, E. durans $(0.4 \%)$ and E. raffinosus $(0.2 \%)$.

Results of antimicrobial susceptibility tests are summarized in Table 2. Frequencies of HLR to aminoglycosides were: $24.8 \%$ to gentamicin

Table 1

Sources of the 455 enterococcal isolates obtained from patients in five hospitals in the city of Porto Alegre, Brazil, from July 1996 to June 1997

\begin{tabular}{|c|c|c|c|c|c|c|c|c|c|}
\hline \multicolumn{10}{|c|}{ Number of strains of each species } \\
\hline Source & E. faecalis & E. faecium & E. gallinarum & E. avium & E. hirae & E. casseliflavus & E. durans & E. raffinosus & Total \\
\hline Urine & 310 & 8 & 0 & 0 & 1 & 0 & 1 & 0 & 320 \\
\hline Secretions & 83 & 2 & 2 & 5 & 2 & 0 & 0 & 0 & 94 \\
\hline Blood & 11 & 0 & 0 & 0 & 0 & 0 & 0 & 1 & 12 \\
\hline Catheter & 10 & 0 & 1 & 0 & 0 & 0 & 0 & 0 & 11 \\
\hline Others & 8 & 3 & 4 & 0 & 0 & 2 & 1 & 0 & 18 \\
\hline Total & 422 & 13 & 7 & 5 & 3 & 2 & 2 & 1 & 455 \\
\hline
\end{tabular}

Table 2

Occurrence of high-level resistance to ampicillin, gentamicin and/or streptomycin and resistance to vancomycin among 455 enterococcal isolates obtained from patients in five hospitals in the city of Porto Alegre, Brazil, from July 1996 to June 1997

\begin{tabular}{|c|c|c|c|c|c|}
\hline \multirow[b]{2}{*}{ Species } & \multirow{2}{*}{$\begin{array}{l}\text { Total isolates/ } \\
\text { total resistant } \\
\text { strains }(\%)\end{array}$} & \multicolumn{4}{|c|}{ Antimicrobial Agent ${ }^{\mathrm{a}}$} \\
\hline & & $\underset{16 \mu \mathrm{Ap} / \mathrm{mL}}{\operatorname{Ap}}$ & $\begin{array}{c}\mathrm{Ge} \\
500 \mu \mathrm{g} / \mathrm{mL}\end{array}$ & $2000 \mu \mathrm{gt} / \mathrm{mL}$ & $\begin{array}{c}\mathrm{Vc} \\
6 \mu \mathrm{g} / \mathrm{mL}\end{array}$ \\
\hline E. faecalis & $181 / 422(42.9 \%)$ & 7 & 107 & 67 & 0 \\
\hline E. faecium & $13 / 13(100 \%)$ & 6 & 5 & 5 & 0 \\
\hline E. gallinarum & $6 / 7(85.7 \%)$ & 0 & 0 & 0 & 6 \\
\hline E. avium & $1 / 5(20 \%)$ & 0 & 1 & 0 & 0 \\
\hline E. hirae & $0 / 3(0 \%)$ & 0 & 0 & 0 & 0 \\
\hline E. casseliflavus & $0 / 2(0 \%)$ & 0 & 0 & 0 & 1 \\
\hline E. durans & $0 / 2(0 \%)$ & 0 & 0 & 0 & 0 \\
\hline E. raffinosus & $1 / 1(100 \%)$ & 1 & 0 & 0 & 0 \\
\hline Total $(\%)$ & $202 / 455(44.4 \%)$ & $14(3.1 \%)$ & $113(24.8 \%)$ & $72(15.8 \%)$ & $7(1.5 \%)$ \\
\hline
\end{tabular}

ap, ampicillin; Ge, gentamicin; St, streptomycin; Vc, vancomycin. 
and $15.8 \%$ to streptomycin. Resistance to both gentamicin and streptomycin was detected in $13(2.8 \%)$ isolates. Fourteen isolates showed HLR to ampicillin (MIC $\geq 16 \mu \mathrm{g} / \mathrm{mL}$ ): seven were identified as E. faecalis, six as E. faecium and one as E. raffinosus. Intrinsec resistance to vancomycin ( $\mathrm{MIC} \geq 6 \mu \mathrm{g} / \mathrm{mL}$ ) was observed in six $E$. gallinarum and one E. casseliflavus. None of the isolates showed $\beta$ lactamase activity.

A total of 174 E. faecalis isolates presenting HLR to aminoglycosides were analysed by PFGE, comprising all 107 with HLR-Ge and all 67 with HLR-St. The results indicated that they were distributed in 26 PFGE patterns clustered at $70 \%$ similarity level. One predominant clonal group was found among the E. faecalis isolates presenting HLR-Ge. This group (named as clonal group A) was composed by 80 (70.8\%) isolates recovered from patients in three hospitals (Irmandade Santa Casa de Misericórdia de Porto Alegre, Hospital da Criança Santo Antônio e Hospital de Clínicas de Porto Alegre [Fig.1]). Such isolates were distributed among 47 highly related PFGE profiles presenting degrees of similarity of $82.7 \% \pm 3.1$. Profiles composing the clonal group A were also related to the profile of a strain representative of the predominant clonal group previously identified among isolates in the cities of Rio de Janeiro and Niterói, Southeast region of Brazil ${ }^{1,12}$. Although studies accomplished in other countries show a great diversity among isolates presenting HLR-Ge $e^{8,15,16,24}$, our results indicate clonal dissemination among three hospitals included in this study. Intra and inter-institution dissemination of this clone in the cities of Porto Alegre and in Rio de Janeiro/Niterói, would be explained by the persistence of a strain with characteristics that would allow its survival, as shown by other investigators ${ }^{5,9}$. On the other hand, MURRAY et al. ${ }^{15}$ demonstrated the occurrence of isolates with indistinguishable profiles, presenting differences in resistance to aminoglycosides.

The remaining isolates were distributed in 25 different PFGE patterns, each one composed by one or two isolates, indicating the large genetic diversity among the isolates that did not belong to the predominant clonal group. Most of the strains presenting HLR to both gentamicin and streptomycin (9/13) were included in this PFGE patterns indicating a higher degree of genetic diversity among isolates with such a phenotype. The remaining four HLR-GeST isolates belonged to clonal group A. This observation is in contrast with other studies performed with isolates from Rio de Janeiro ${ }^{10,18}$. The profiles of the isolates with resistance included in group A were similar, reinforcing the hypothesis of the presence of strains with "properties" that contributed to their prevalence and dissemination.

Figures 2 and 3 illustrate the genetic diversity among E. faecalis and E. faecium isolates presenting HLR-St. The absence of a predominant PFGE clonal group among E. faecalis isolates presenting HLR-St was in agreement with previous observations with Brazilian isolates ${ }^{1,10}$. The high degree of genetic diversity of the E. faecalis isolates with HLR-St may be indicative of community origin and that infections caused by these enterococci may be predominantly endogenous. It is interesting to note that $E$. faecium isolates also presented a high degree of genetic diversity, contributing to the hypothesis that sporadic infections caused by this microorganism are mostly endogenous.
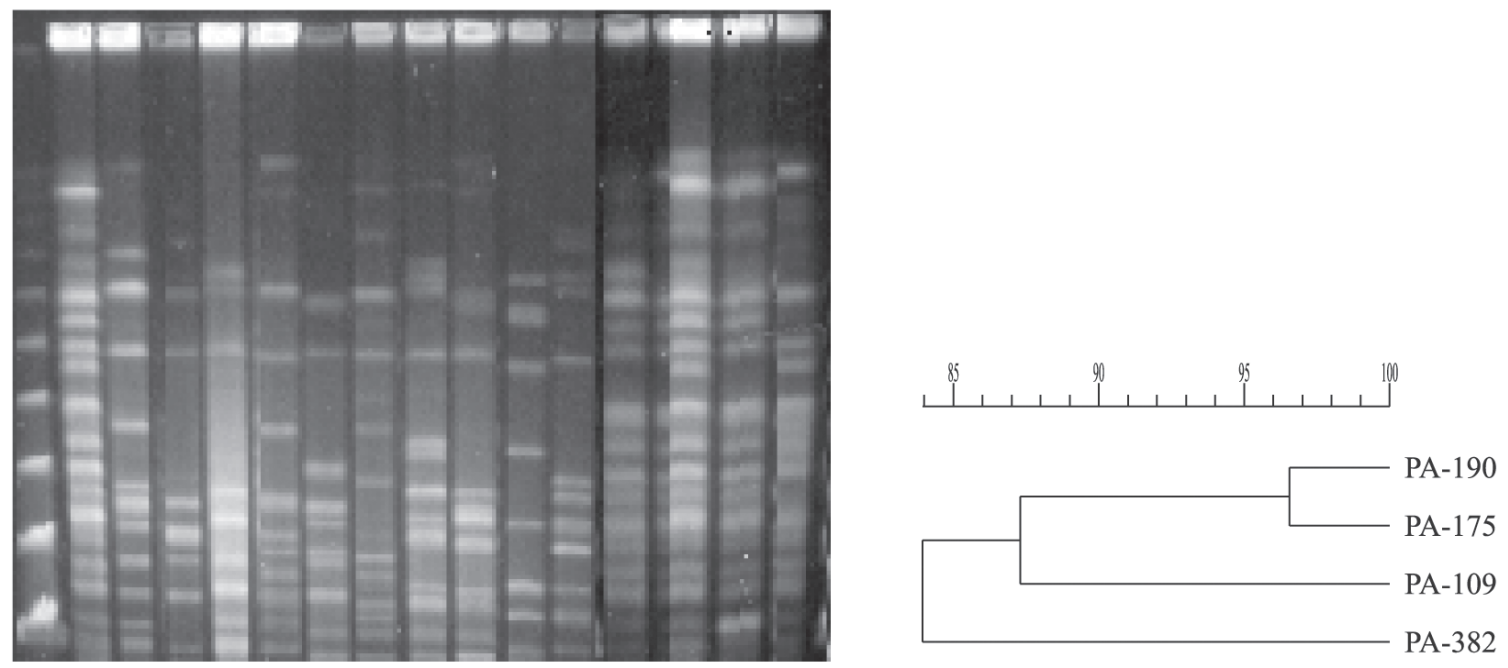

ISCMPA: Irmandade Santa Casa de Misericórdia de Porto Alegre HCPA: Hospital de Clínicas de Porto Alegre HCSA: Hospital da Criança Santo Antônio

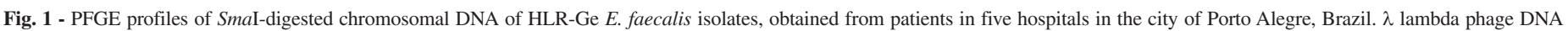

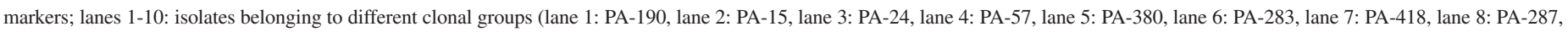

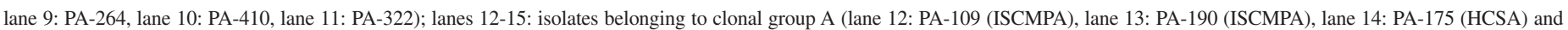
lane 15: PA-382 (HCPA)). 
A

$\lambda 123456 \lambda 78910111213141516 \lambda$

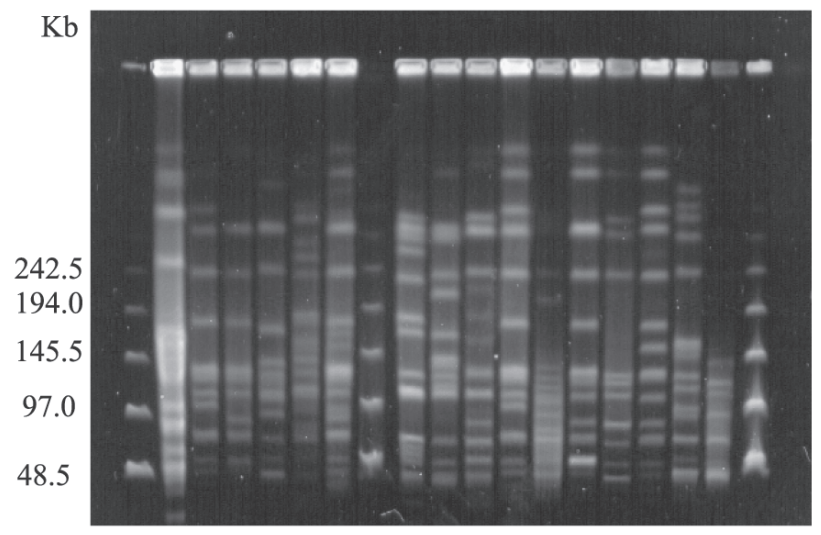

B

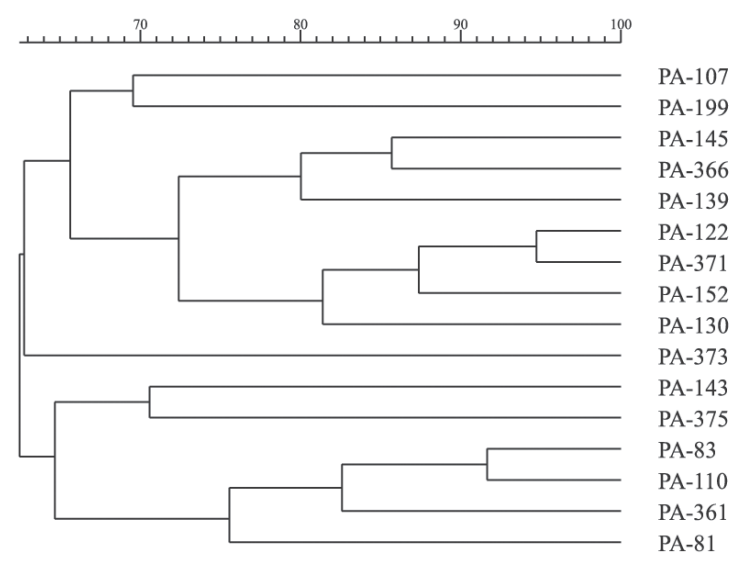

$\lambda$ : lambda phage DNA markers; lanes 1 to 5 : strains nosocomial isolated of ISCMPA (PA -107; PA-122; PA-130; PA-152; PA-199); lane 6: strain nosocomial isolated of HCPA (PA -371); lanes 7 to 12: strains isolated of ISCMPA (PA -81; PA -83; PA -110; PA -139; PA-143; PA-145); lanes 13 to 16: strains isolated of HCPA (PA-361; PA-366; PA-373; PA-375).

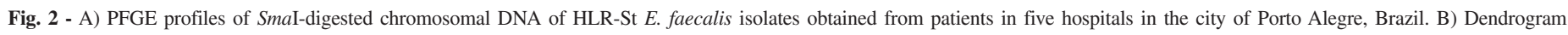
resulting from a computer-assisted analysis of PFGE profiles of HLR-St E. faecalis isolates shown in A.

\section{$\mathbf{A}$}

$\begin{array}{llllllllllllll}\lambda & 1 & 2 & 3 & 4 & 5 & 6 & 7 & 8 & 9 & 10 & 11 & 12 & 13\end{array}$

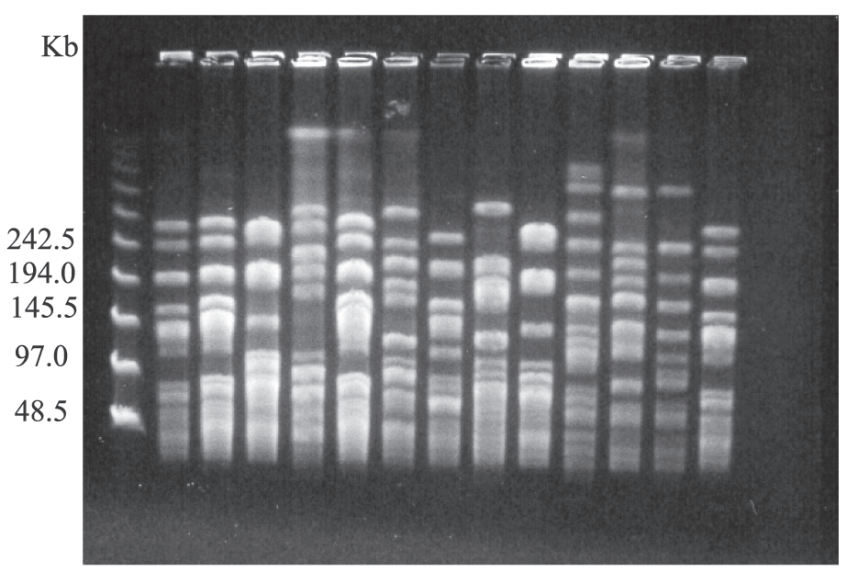

B

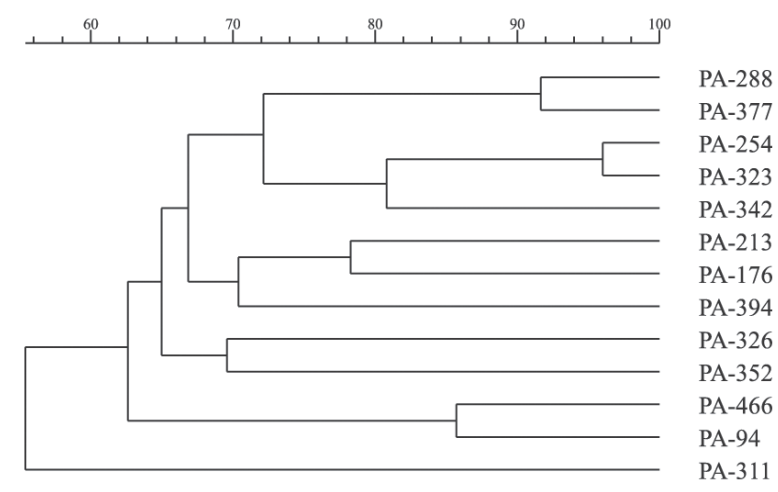

$\lambda$ :lambda phage DNA markers; lane 1:PA-213, lane 2: PA-254, lane 3: PA-288, lane 4: PA-311, lane 5: PA-323, lane 6: PA326, lane 7: PA-342, lane 8: PA-352, lane 9: PA-377, lane: PA-394, lane 11: PA-466, lane 12: PA-94, lane 13: PA-176.

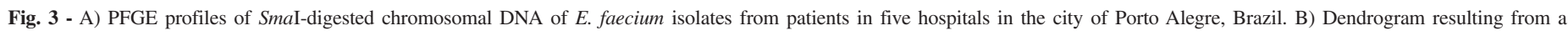
computer-assisted analysis of PFGE profiles of E. faecium isolates shown in A.

In summary, the present study describes the phenotypic and genotypic characteristics of enterococcal isolates circulating in five hospitals located in the city of Porto Alegre, Brazil, during 1996 to 1997. These data serve as a basis for additional surveillance studies of infections caused by these microorganisms. The results indicate intra and inter-hospital dissemination of a predominant clone of E. faecalis presenting HLR-Ge in the hospitals included in this study. 


\section{RESUMO}

\section{Diversidade genética e resistência aos antimicrobianos de amostras de enterococos isoladas na região Sul do Brasil}

Foram estudadas 455 amostras de enterococos isolados de pacientes moradores da cidade de Porto Alegre, Rio Grande do Sul, Brasil, durante o período de julho 1996 a junho 1997 e foram identificados ao nível de espécies por testes fisiológicos convencionais e analisados sua susceptibilidade aos agentes antimicrobianos. A diversidade genética foi avaliada por eletroforese de campo pulsado ("pulsed-field gel electrophoresis", PFGE) com a enzima de restrição SmaI. A espécie mais freqüente encontrada foi o Enterococcus faecalis $(92,8 \%)$. As outras espécies identificadas foram: E. faecium $(2,9 \%)$, E. gallinarum (1,5\%), E. avium (1,1\%), E. hirae $(0,7 \%)$, E. casseliflavus $(0,4 \%), E$. durans $(0,4 \%)$ and $E$. raffinosus $(0,2 \%)$. A prevalência de amostras com níveis elevados de resistência (HLR) aos aminoglicosídeos foram de $37,8 \%$. HLR para gentamicina foi encontrada em $24,8 \%$ das amostras. Nenhuma amostra com resistência adquirida à vancomicina foi isolada. A análise através de PFGE revelou a predominância do grupo clonal A, constituído por amostras isoladas de diferentes materiais clínicos obtidos de pacientes internados em três hospitais. Esses resultados sugerem a disseminação intra e inter-hospital de um clone predominante, composto por amostras de E. faecalis apresentando níveis elevados de resistência a gentamicina, nos hospitais incluídos neste estudo.

\section{ACKNOWLEDGMENTS}

This study was supported in part by Fundação de Amparo à Pesquisa do Estado do Rio Grande do Sul (FAPERGS), Conselho Nacional de Desenvolvimento Científico e Tecnológico (CNPq), Fundação de Amparo à Pesquisa do Estado do Rio de Janeiro (FAPERJ), Ministério da Ciência e Tecnologia (MCT/PRONEX), and Fundação Faculdade Federal de Ciências Médicas de Porto Alegre (FFFCMPA). We also thank the staff of diagnostic laboratories of the health institutions included in the present study for providing enterococcal strains.

\section{REFERENCES}

1. CARVALHO, M.G.S. - Caracterização bio-epidemiológica de Enterococcus e microrganismos relacionados, com ênfase na aplicação de técnicas moleculares. Rio de Janeiro, 1998. (Tese de Doutorado - Instituto de Microbiologia da Universidade Federal do Rio de Janeiro).

2. ENDTZ, H.P.; VAN DEN BRAAD, N.; VAN BELKUM, A. et al. - Comparison of eight methods to detect vancomycin resistance in enterococci. J. clin. Microbiol., 36: 592-594, 1998.

3. FACKLAM, R.R. \& TEIXEIRA, L. M. - Enterococcus. In: COLLIER, L.; BALOWS, A.; SUSSMAN, N. \& EDWARD, A., ed. Topley \& Wilson's Microbiology and microbial infections. 9 ed. London, 1997. p. 669-682.

4. FACKLAM, R.R.; SAHM, D.F. \& TEIXEIRA, L.M. - Enterococcus. In: MURRAY, P.R.; BARON, M.A.; PFALLER, M.A.; TENOVER, F.C. \& YOLKEN, R.H., ed. Manual of clinical Microbiology. 7 ed. Washington, ASM Press, 1999. p. 297-305.

5. FRIDKIN, S.K.; YOKOE, D.S.; WHITNEY, C.G.; ONDERDONK, A. \& HOOPER, D.C. - Epidemiology of a dominant clonal strain of vancomycin-resistant Enterococcus faecium at separate hospitals in Boston, Massachusetts. J. clin. Microbiol., 36: 965 $970,1998$.
6. GIGLIO, M.M.S.; PINTO, C.M.E.; CÓRDOVA, J.E.; ESCANDAR, D.P. \& WAMAN, M.C. - Identificación de especies de Enterococcus en muestras clínicas y susceptibilidad a agentes antimicrobianos. Rev. med. Chile, 124: 70-76, 1996.

7. GORDON, S.; SWENSON, J.M.; HILL, B.C. et al. - Antimicrobial susceptibility patterns of common and unusual species of enterococci causing infections in the United States. J. clin. Microbiol., 30: 2373-2378, 1992.

8. LLOYD, S.; ZERVOS, M.; MAHAYNI, R. \& LUNDSTROM, T. - Risk factors for enterococcal urinary tract infection and colonization in a rehabilitation facility. Amer. J. infect. Control, 26: 35-39, 1998.

9. MA, X.; KUDO, M.; TAKAHASHI, A. \& TANINOMOTO, K.I.Y. - Evidence of nosocomial infection in Japan caused by high-level gentamicin-resistant Enterococcus faecalis and identification of the pheromone-responsive conjugative plasmid encoding gentamicin resistance. J. clin. Microbiol., 36: 2460-2464,1998.

10. MENDONÇA, C.R.V. - Ocorrência e diversidade genética de enterococos, apresentando resistência a níveis elevados de antimicrobianos, isolados em quatro instituições de saúde na cidade do Rio de Janeiro. Rio de Janeiro, 1998. (Dissertação de Mestrado - Instituto de Microbiologia da Universidade Federal do Rio de Janeiro).

11. MERQUIOR, V.L.C.; PERALTA, J.M.; FACKLAM, R.R. \& TEIXEIRA, L.M. - Analysis of electroforetic whole-cell protein profiles as a tool for characterization of Enterococcus species. Curr. Microbiol., 28: 149-153, 1994.

12. MONDINO, S.S.B.; CASTRO, A.C.D.; MONDINO, P.J.J. et al. - Phenotypic and genotypic characterization of clinical and intestinal enterococci isolated from inpatients and outpatients in two Brazilian hospitals. Microb. Drug Res., 9: 167174, 2003.

13. MORRISON, D.; WOODFORD, N. \& COOKSON, B. - Enterococci as emerging pathogens of humans. Soc. appl. Bact. Symp., 83 (suppl.): S89-S99, 1997.

14. MURRAY, B.E. - The life and times of the Enterococcus. Clin. Microbiol. Rev., 3: 46$65,1990$.

15. MURRAY, B.E.; SINGH, K.V.; HEATH, J.D.; SHARMA, B.R. \& WEINSTOCK, G.M. Comparison of genomic DNAs of different enterococcal isolate using restriction endonucleases with infrequent recognition site. J. clin. Microbiol., 28: 2059-2063, 1990.

16. MURRAY, B.E. - Diversity among multidrug-resistant enterococci. Emerg. infect. Dis., 4: $37-47,1998$.

17. NATIONAL COMMITTEE FOR CLINICAL LABORATORIES STANDARDS Methods for dilution antimicrobial susceptibility tests for bacteria that grow aerobically. Wayne, NCCLS, 1999. (Documents M7-A5 and M100-S9).

18. PAULA, G.R. - Análise da diversidade genética de amostras de enterococos obtidas no Hospital Universitário Clementino Fraga Filho da Universidade Federal do Rio de Janeiro de 1995-1997. Rio de Janeiro, 2000. (Dissertação de Mestrado Instituto de Microbiologia da Universidade Federal do Rio de Janeiro).

19. SCHABERG, D.R.; CULVER, D.H. \& GAYNES, R.P. - Major trends in the microbial etiology of nosocomial infections. Amer. J. Med., 91(suppl. 3B): s72-s75, 1991.

20. STERN, C.S.; CARVALHO, M.G. \& TEIXEIRA, L.M. - Characterization of enterococci isolates from human and nonhuman sources in Brazil. Diagn. Microbiol. infect. Dis., 20: 61-67, 1994

21. TEIXEIRA, L.M.; CARVALHO, M.G.S.; MERQUIOR, V.L. et al. - Phenotypic and genotypic characterization of Vagococcus fluvialis, including strains isolated from human sources. J. clin. Microbiol., 35: 2778-2781, 1997.

22. TENOVER, F.C.; ARBEIT, R.D.; GEORING, R.V. et al. - Interpreting chromosomal DNA restriction patterns produced by pulsed-field gel electrophoresis: criteria for bacterial strain typing. J. clin. Microbiol., 33: 2233-2239, 1995. 


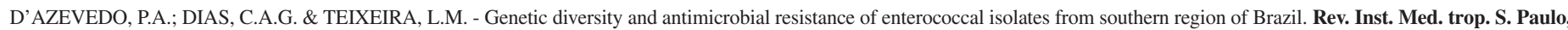
48(1): 11-16, 2006.

23. TENOVER, F.C.; ARBEIT, R.D. \& GEORING, R.V. - How to select and interpret molecular strain typing methods for epidemiological studies of bacterial infections: a review for healthcare epidemiologists. Molecular Typing Working Group of the Society for Healthcare Epidemiology of America. Infect. Control Hosp. Epidemiol., 18: 426-439, 1997.

24. THAL, L.A.; CHOW, J.W.; PATTERSON, J.E. et al. - Molecular characterization of highly gentamicin-resistant Enterococcus faecalis isolates lacking high-level streptomycin resistance. Antimicrob. Agents Chemother., 37: 134-137, 1993.
25. VANDAMME, P.; VERCAUTEREN, E.; LAMMENS, C. et al. - Survey of enterococcal susceptibility patterns in Belgium. J. clin. Microbiol., 34: 2572-2576, 1996.

Received: 11 November 2004

Accepted: 26 October 2005 